\title{
政策形成技法としての政策移転ガイドライン： 既往研究からの知見
}

\author{
POLICY TRANSFER GUIDELINE AS A POLICY-MAKING TOOL: A REVIEW
}

\author{
松浦 正浩 ${ }^{1}$ \\ ${ }^{1}$ Ph.D. (Urban and Regional Planning) 東京大学大学院特任准教授 公共政策学連携研究部 \\ (E-mail:matsuura@pp.u-tokyo.ac.jp)
}

\begin{abstract}
政策形成において海外の先行事例は少なからず影響を与えている. 特に 1990 年代以降, 欧州連合の発足 と経済のグローバル化により, 政策形成において海外の先行事例が影響を与える現象, いわゆる政策移転 に対する関心が高まり, 事例研究が行われてきた. しかし, 政策移転研究の大半は事例研究に基づく記述 説明で，政策形成の現場に関わる者に対する技術的アドバイスとして，政策移転の方法論を多面的に検討 した研究は少ない. 本稿は, 政策移転研究を概観した上で, 既往研究に基づき, 政策形成技法としての政 策移転の方法論を検討したうえで，政策移転に取り組む目的と対象に基づき，適切な政策移転の方法論の 選択を促す政策移転ガイドラインを提示する.
\end{abstract}

\section{キーワード : 政策移転, 学習導出, 政策形成技法}

\section{1. はじめに}

\section{1. 日本の政策形成における海外事例の役割}

政策提案がなされる場合, 提案の根拠や背景として, 海外の先行事例への参照が頻繁に行われている. たとえ ば, 平成 20 年度中に開催された環境省の中央環境審議会 およびその部会では，提出された資料（参考資料含む） 383 点中 139 点, 寸なわち資料全体の約 36\%において海 外の動向への言及がみられる i。. また, 日本の政策形成 における海外事例の重要性は以前から指摘されており, たとえば Campbell ${ }^{11}$ 「早本の政策的解決策の大半は, 多か水少なか水海外に由来寸る」とまで述べている. 海外事例は，日本に適した政策を検討寸る際に参考と して, 行政機関や研究機関が自ら主体的に海外事例を参 考とする場合のほかにも,「日米規制改革および競争政策 イニシアティブに基づく要望書（いわゆる年次改革要望 書)」のように, 海外からの圧力という形で影響を及ぼす こともある ${ }^{2}$. よって, 海外事例は, 参考情報という役 割のほかにも, 外圧という役割も果たしている.また, 個別の政策案件のみならず，国家の制度設計にも海外事 例の影響は見られる. 近年では, 司法制度改革の一環と しての裁判員制度の導入においても海外の陪参審制度が 参考とされているほか ${ }^{3)}$, 明治政府による警察等の制度 設計においても，海外事例が参考にされている ${ }^{4}$.

これらの事例に見られるように, 日本の政策形成の多 くの場面で，海外事例が一定の影響を及ぼしていること は確かである. しかし，日本における政策形成全体を見
通した上で, 海外事例がどの程度の影響があるのか, ど のように影響を及ぼしているのかについては，今後の実 証研究が待たれるところである.

\section{2. 日本の政策形成に関する政策移転研究}

海外などにおける先行事例が政策形成において影響を 与えるメカニズムについては，政策移転 (policy transfer) という枠組みで，近年，特に欧州連合発足後の欧州にお いて活発に議論されている. その枠組みなど, 海外にお ける政策移転研究については後ほど詳述するが，ここで は, 日本における政策形成事例について, 政策移転の観 点から検討を加えた研究について概観しておく.

Nakano5)は，独立行政法人化において，英国のエージ エンシー化事例が利用された事例に着目し, 英国では公 共サービスの効率的な提供という目的で導入された政策 が，日本では公務員削減という政治公約に一致させるた めに変容した過程を明らかにしている. Goldfinch ${ }^{6}$ は, 国立大学法人化を取り上げ, 同様に英国のエージェンシ 一化に影響を受けているにもかかわらず，文部科学省が 「改革の儀式」を通過しつつも, 大学への影響力を維持 寸るために, 外見だけのシンボル的な政策移転を行った と分析している. 秋吉 ${ }^{7}$ は, 航空輸送産業における規制 緩和において，米国のアイディアが参照されたものの，

「学習の歪外などが原因となり日本における規制緩和 はきわめて限定的なものとなり, 政策効果が挙げられな かったとしている. Matsuura ${ }^{8)}$ は, 徳島における国道交差 点改良に関する合意形成の実践を米国の政策形成手法の 
移転ととらえ，政策形成手法の移転においては，適応化 (adaptation) と同時に, 組織変革（organizational change） も必要であることを明らかにしている.

これらの研究は, 日本の政策形成事例における海外事 例の影響について，その実態を詳細に明らかにしている が, 今後の政策形成において, 海外事例をいかに活用で きるかという, 社会技術としての実践的な知見の導出に までは至っておらず, 今後, さらなる検討が必要である.

\section{3. 研究の背景と方法論}

これまで見てきたように，政策移転に関する検討はす でに始まっているが，政策形成システムのなかで海外事 例を適切に活用寸る方法論についての検討は十分に行わ れていない，明治政府の「文明開化」政策のように, 海 外と同じ制度を導入することそのものが否定し得ない絶 対的な規範だと措定すれば, 海外事例活用の適切な方法 論を検討する必要はないだろう。しかし，GDPで世界第 2 位となり, マハティールのルックイースト政策のよう にアジア諸国がその政策を参考とする現代の日本では, 欧米諸国の政策に追随すること自体を政策形成における 最高次の目標とすることは明らかに不適切で, むしろ国 内諸制度を考慮し，政策移転を必要とする個別の政策形 成過程に合った政策移転の方法論が必要である.

本研究では, 政策の検討において海外事例を適切に活 用するガイドラインについて検討する. 研究の方法論は, 既往研究のレビューにより国内外の政策移転事例につい て整理したうえで, 具体的な海外事例活用の方法論につ いて，それらの事例をもとに検討を進める.

\section{2. 研究としての政策移転}

\section{1. 政策移転に関する研究の概要}

政策移転は, 公共政策の研究対象として, 1992 年のマ 一ストリヒト条約締結による欧州連合発足以降, 特に欧 州において関心が高まっている研究領域である. 政策移 転は, Dolowitz と Marsh ${ }^{9}$ により研究の方法論が提示され て以降, 特定の分析枠組みとしてとらえることもあるが, また同時に, 政策に関連する概念, 目標, 事業, 制度な ぞが，行政単位（国際機関，国，自治体等）間，または 時間を越えて移転する現象全般を指示することもある ii). 後者の意味合いでの政策移転については，これまで多様 な観点から事例研究と分析枠組みの構築が進められてき た. 比較的歴史の長いものとしては, 政策波及論 (policy diffusion) や政策収斂論（policy convergence）と呼ばれる 研究で, ある地域で実施された政策が他の地域で次々と 模倣されていく過程, あるいは, 多数の異なる地域で同 様の政策が導入されていく過程に関寸る研究である.こ
れらの政策研究は, 移転過程よりも結果としての政府間 の類似についての比較検討に主眼が置かれている. 1990 年代に入り, Richard Rose ${ }^{10)}$ が学習垍出 (lesson-drawing) の概念を提示したことで, 移転過程に着目した検討枠組 みの形成が加速する.1990年代半ばには, David Dolowitz ${ }^{9}$ をはじめとする欧州の研究者が，自主的な学習ではなく 国際機関等から強制的に受け入れを要求される形の政策 形成を含めた, 総合的な政策移転論を発表し, 政策移転 に関する関心が大きく高まる。 また Martin de Jong ${ }^{11)} は$, 組織体制や法といった制度の移転に着目し, 臟器移植と のアナロジーで制度移植（institutional transplantation）と いう概念を提起しており, 検討に值する.本章では以下, これらの分析枠組みついて, 既存研究を概観する.

\section{2. 政策波及論, 政策収斂論}

政策立案において, 海外や国内の他の自治体や州政府 の先行事例を参照することは決して最近の現象ではない. たとえば，1931 年に米国カリフォルニア州が制定した Fair Trade Law は, 米国内の多くの州で模倣され, 一部の 州では誤植さえ残されたまま模倣されている ${ }^{12}$.

ある特定の国，自治体等で成功を収めた政策が，他の 地域でも次々と導入されていく過程と, その原因につい ての分析は, 政策波及論研究として 1960 年代より存在し た.たとえば, Walker ${ }^{12)}$ は, 米国州政府に着目し, 政策 イノベーションを創出している州政府, 早期に模倣する 州政府，追随が遅れる州政府を統計的に分析した論文を 1969 年に発表している. また, Majone ${ }^{13)}$ は, 欧州の規制 政策が, 戦後継続して米国の影響を受けていることを明 らかにしている。

また, 複数の国, 自治体等が類似寸る政策を導入して いく過程に着目した研究は政策収斂論として, 同様に 1990 年代以前から存在している. 政策波及論と政策収斂 論の違いは, 前者が先行事例と後発事例の関係性に特に 注目するのに対し, 後者は結果として同様の政策が導入 された原因に注目寸る点にあると考えられる.しかし， Bennett ${ }^{14}$ は政策収斂論のレビューで, 先行事例の模倣過 程も重視しており, 政策波及論と政策収斂論の峻別は困 難で，また両者に大きな差はないと考えられる.

これら初期の政策移転に関する研究は, 主に比較政治 学の文脈で進められ，客観的な立場から政策の類似性を 説明する研究として進められている.

\section{3. 学習導出論}

Richard Rose ${ }^{10,15)}$ が提唱した政策移転のモデルのひと つで, 従来の政策波及論が，過去に起きた現象の説明に 傾倒していること, 同じ社会問題には同じ解決策が有効 としていることを問題視し，より実践的な方法論として， 国内の政策形成において, 海外の先行事例を活用寸るプ 


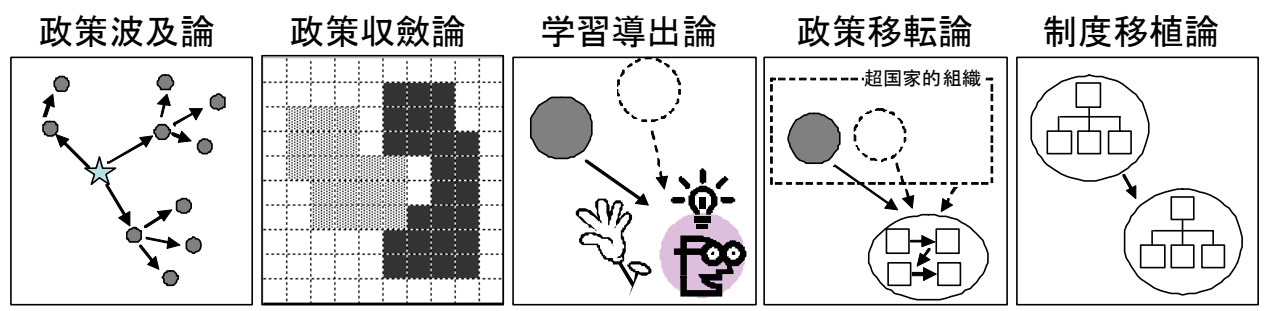

Fig. 1 政策移車云研究の概念整理

ロセスの一般化を試みている. Rose は, 現状への不満 (dissatisfaction) から学習導出が始まると仮定している が，これは，政治的圧力などに起因しない自主的，かつ 合理的な政策形成プロセスを前提としており，政治的プ ロセスを前提とする他の研究枠組みと比較して，学習導 出論の特徵となっている. 学習導出の方法としては, 海 外の政策をほぼそのまま導入する複写 (copying), 状況 に合わせて一部修正して導入する適応化 (adaptation), 2 つ先行事例を組み合わせて導入するハイブリッド化 (making a hybrid)，3つ以上の先行事例の共通要因を組 み合わせて導入する調合 (synthesis), そして検討の契機 として先行事例を活用するひらめき（inspiration）の5つ が挙げられている ${ }^{15)}$.

\section{4. 政策移転論}

政策移転論は，「異なる政策・社会システムで発生した アイディア, 制度, 事業, 政策に基づいて, 事業, 政策, 制度などをある政治・社会システムにおいて設計するこ と, そしてその過程」16)を対象とした研究で, 学習導出 の流れを汲みつつ，学習導出が想定する自主的な政策移 転だけでなく，超国家的組織（supranational institutions） などによる強制的な政策移転も対象としている ${ }^{9), 15), 17) . ~}$ 政策波及論から続く一連の政策移転研究を総括する試み として, 1990 年代から関心が高まっているが, 特に, 1990 年代以降, 国際政治では国連や EU といった国際レジー ムの台頭 ${ }^{18)}{ }^{19)}$, 東西冷戦の終結 ${ }^{20), 21)}$, 経済ではいわゆる グローバル化による国際依存関係の強化などが要因とな り，政策移転論への関心が高まった。

Dolowitz と Marsh ${ }^{17)}$ は, 政策移転研究の枠組みとして, 以下の $7 つ の$ 質問から構成される研究の視点を提示した.

・なぜアクターは政策移転に関わるか

・政策移転過程に関わる主要アクターは誰か

・何が移転されるのか

・どこから学習は導出されるのか

・移転の度合いはどのように異なるのか

・政策移転を促進，抑止するのは何か

・政策移転過程は政策の「成功」「失敗」によ゙う 関係するのか

それぞれの視点について，事例研究に基づく類型化が試
みられているが，いずれも多様性を強調した分析となっ ている.たとえば，移転の内容については7類型，アク ターについては9類型を提示している. また,「失敗」に つながる政策移転の3 類型として，対象に関する情報が 不十分な移転 (uninformed transfer), 先行事例の主要要素 が移転されなかった不完全な移転 (incomplete transfer), そして 2 国間の経済, 社会, 政治, イデオロギーの違い に十分な配慮をしなかった不適切な移転（inappropriate transfer）を挙げている ${ }^{17)}$.

政策移転論では，移転事例そのものだけでなく，背後 にある構造的要因への関心も高く, Evans と Davies ${ }^{22)}$ は, Giddens の構造化理論 ${ }^{23)}$ を参照し, 構造とエージェント の関係に着目し，政策移転の促進・制約条件となる構造 的要因（たとえばグローバリゼーション）への着目を促 している. 同様に, Bomberg と Petersen ${ }^{24)} は$, 欧州化 (Europeanization) と政策移転論の関係を模索している. アクターについては, Evans ら 22, 25)が，アクターとプ ロセスから成る政策移転ネットワーク（policy transfer network）の枠組みを提示し, 政策移転の比較事例分析を 試みている. Stone ${ }^{26) や L a d i}{ }^{19)}$ は，政策移転のエージェン トとして，シンクタンク，政策研究機関 (policy research institution）の役割に注目し，これらが政策移転で重要な 役割を果たしていることを明らかにしているほか，シン クタンクという組織そのものを米国からアジアへ移転し ようとする動きについても言及している.

また，いわゆるグローバリゼーションにより， New Public Management などの新自由主義政策が, OECD 諸国 に限らず発展途上国にも影響を及ぼし始めたことも，政 策移転論への関心の高まりにつながっており，これらの 事例を検証した論文も多数発表されているが 27),28), 本稿 の冒頭で紹介した日本の事例に関する論文もこの流れに 位置づけることもできる.

\section{5. 制度移植論}

臓器移植のアナロジーから生まれた法移植論（legal transplantation）の影響を受け，海外の制度が模倣された 際，人間の臓器と同じように，政府という体内で機能し 続けるのか，拒絶反応を示すのかという関心からデルフ 卜工科大の Martin de Jong ${ }^{11), 29)}$ によって提唱された枠組み 
が制度移植論である. 政策移転論と比較して, 構造的要 因への関心が高く, 学習垍出論に見られるエージェント の自発的行為だけでなく, 社会構造への適合性 (goodness of fit）という観点から，国家の諸特性に関する「国家の 家系 (families of nations)」概念を用いて, 移植の可能性 を模索している.

\section{6. 政策移転研究のまとめ}

これまでに見てきた政策移転に関する議論は Fig. 1 の ように整理することができる，政策波及論と政策収斂論 はマクロレベルでの研究であり, 統計的手法を用いた研 究も多い30). 学習導出論以降は, 個別の移転事例一の注 目が始まる. 学習導出論では, 先行事例から学ぶという 受入側の自主的取り組みに着目していたが，政策移転論 では受入側の自主性に拘らず移転の現象全般を取り扱っ ている. また制度移植論は, 制度に特化した検討を行っ ている. これらの社会科学研究は, その大半が現象の理 解による記述, 説明であり, 次章で述べるように方法論 を提示しているものは僅かである.

\section{3. 技術としての政策移転}

\section{1. 処方箋の欠如}

学習導出論は，政策形成の方法論に着目しており，近 年の政策移転に関する研究も, 比較政治学を中心とした 現象の説明から, より実践的な知見の導出一と移行して いるはずであるが，実際には政策移転の過程や要因を説 明する実証研究が大半である. Evans ${ }^{25}$ は, 政策移転に関 する分析の焦点として以下の3つを挙げている.

・記述 (description) 政策移転がどのように行われたか

・説明 (explanation) 政策移転がなぜ行われたか

・処方 (prescription) 政策移転をどのように行うべきか そして, これらのうち, 特に欧州では社会科学の中立性 維持を理由に, 「処方」に該当する研究が意図的に避けら れていることを指摘している ${ }^{25)}$. このように, 本稿が着 目寸る社会技術としての政策移転に関寸る研究は少ない ものの, 関連する知見を以下概観する.

\section{2. 学習導出論}

Roseの学習導出論は, 研究の方法論であるほか, 政策 移転の方法論としても提示されている. Rose ${ }^{31}$ は以下の 10 段階からなる学習導出のモデルを示している.

(1) 主なコンセプトを学習する

(2) 政策家の関心を集める

（3）複数案を走査し学習対象の恓らいを定める

(4) 海外に行って学習する

（5）観察をもとに，海外の事業がどのように機能して
いるかについて，一般化したモデルをつくる

(6) そのモデルを，自分自身の国の文脈に合わせ，学 習を導出寸る

(7) 導出した学習を採用するか判断する

(8) 導出した学習を適用できるか判断する

（9）導出した学習の手段と目標を単純化し, 成功の可 能性を高める

(10) 期待される成果を評価するとともに, 採用された 場合は継続的に評価する

しかし，10段階から成るリニアモデルは，古典的な政策 分析論のように合理的な意思決定を前提としており,「ご み箱モデル」32)などで表現される現実の政策形成過程と 一致しないとして一部から批判を受けている ${ }^{33)}$.

\section{3. 政策移転ネットワーク}

Evans ${ }^{22,}$, 25)や Ladi ${ }^{19)}$ が提案している政策移転ネットワ ークの概念は, 研究のための分析枠組みであるが, 実践 の方法論としてとらえることもできる. 政策移転ネット ワークは, Haas の認知共同体 ${ }^{34)}$ や Sabatier ${ }^{35)}$ の唱道連携 フレームワークの概念を参考した, 政策移転の中心的役 割を果たすアクターのネットワークに関する概念である と同時に，(1) 認識, (2) 模索, (3) 接触, (4) 情報流通 ネットワークの発生, (5) 認知と受容, (6) 移転ネットワ 一クの発生, (7) エリートと認識の動員, (8) 相互作用, (9) 評価, (10) 決定, (11) 実行, (12) 結果の 12 段階か ら成る政策移転のモデル過程を提示している ${ }^{25)}$.この 1 2 段階は，事例研究において移転過程を記述するための 方法論として用いられており, 政策家へのアドバイスで は決してない. しかし，政策移転を試みようとする者に とっては, 移転過程の見取り図として活用することもで きるだろう.

\section{4. 予備的政策評価としての政策移転論}

政策移転論が処方的知見を提供していない批判につい ては既に述べたが，その批判に対応して， Mossberger と Wolman ${ }^{30}$ は, 政策移転を予備的政策評価（prospective policy evaluation）と位置づけ，政策移転を実施する段階

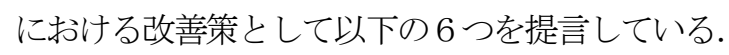

・参考事例の選定は, 幅広く全体を見通した調査をし た後に, 受入側の事情を考慮して重要な事例をいく つか詳しく調査する混合走査法を活用するととも に，情報源を複数にする

・先行事例の問題や批判に注意を向ける

・受入側の既存の政策目標との䚆踥に配慮する

・すべて模倣するのではなく, 必要に応じて限定的な 導入や先行事例の評価にとどめる

・受け入れに必要な政策や制度の必要性を認識する

・不確実性を認識した上で，パイロット事業などを用 
いて漸進的に導入する

\section{5. 制度移植論}

de Jong ${ }^{36)}$ の制度移植論においても，具体的提案の重要 性が指摘されており, 制度移植の成功要因として以下の 9つを挙げている.

・制度の存在について自覚する

・微妙なものも含めて制度の相違を考慮する

・コネを利用できる国内の庇護者を動員する

・学習と交涉のため多様な情報源から知見を得る

・不確実性，曖昧さに注意するとともに寛容になる

・法律ではなく実際の事業から知見を得る

・積極的に動き, 緊迫感, 停滞感, 危機感を醸成する

・提案する海外制度を，一部の人がなぜじうして好む のか，他の人々が好まないのかを事前に予想する

・国際的な実務コミュニティの中で活動し, 双方向学 習を通じて知見を体得する

\section{6. その他}

政策移転研究の文脈とは少し離れるが，実質的に政策 移転に関する技術的知見を与えている研究もある。第一 に, 国際 NGO 研究の分野が参考になる. Wapner ${ }^{37}$ は, 環境 NGO の国際戦略として, 環境保全を推進させたい 国において，国民の環境に関する認識，たとえば鯨や漢 方薬の材料となる動物に対する認識を変容させるため, 映画や音楽を用いて影響を与えようとしている実態を明 らかにしている。 また，Keck と Sikkink $\left.{ }^{38}\right)$ は, 途上国等 の NGO が，自国の政策を変えたくても政治体制等が理 由で影響力がない場合，まず他国の NGO と連携し，連 携先の NGO が他国の政府に圧力をかけ，そして他国政 府から自国政府へと圧力がかかるようにするという，ブ 一メラン戦略の存在を示している. 第二に, 個別の政策 分野において政策移転を推進寸るための資料も参考にな る. たとえば, Connors ${ }^{399}$ は市民参加を海外に広めるため の戦略として, 対象国や地域のプロファイルを作成し, 政治的リーダ一等に市民参加の意義を説明することを勧 めている.

\section{4. 政策移転のガイドライン}

\section{1. 社会技術としての政策移転の方法論}

これまで，政策移転に関連する多様な既往研究を概観 してきたが，前章で述べたとおり，政策移転をこれから 行おうとする者に具体的示唆を与える研究は数少ない. 制度分析によって，政策移転とそのアクターの行動を実 証主義的に説明するだけでは, アクターたちの相互作用 によって構造たる制度が変化する可能性 ${ }^{23}$ を考慮しない
決定論に陥っているほか，政策移転を技術として活用し ようとする政策家への実用的示唆に乏しい. また, 学習 導出論など，政策移転を合理的な情報収集手段と位置づ ける考え方では, 日本の事例に多々見られる表面的な政 策移転や，超国家的組織による改革圧力への対応として の政策移転などをカバーできていない.

本稿では以下，既往研究を参考に，政策形成技術とし ての政策移転について，具体的な方法論を提示し，既存 研究で整理されている政策移転事例を参照しながら, ガ イドラインを仮説として提示寸る.

\section{2. 目的設定}

実際の政策形成過程の観察では, 政策導入の目的は多 様なステークホルダー間で異なることが知られており, 客観的立場から政策移転の目的を一意に定めることは難 しい，そこで，政策形成技法として政策移転の方法論を 活用する政策家 (policymaker) の視点に立脚して, 政策 移転の目的を考える必要がある.これまでに整理した既 存文献によれば，目的は以下の 3 つた別できる.

・社会改革

・課題解決

・生存・適合

第一の目的は，政策家自身が理想とする社会を実現する ために, 海外の事例を説得材料として選択的に利用する 政策移転である.たとえばBennett ${ }^{41}$ は, 海外事例を参照 する理由として5類型を挙げているが，その中に「ある 課題を政治的アジェンダにのせること」,「すでに存在す る結論を正統化 (legitimize) すること」を含めることで, 海外事例を選択的に利用寸る実態も明らかにしている. 具体的には, 米国による年次改革要望書などを活用した 構造改革への圧力 ${ }^{2)}$, 環境 NGO による捕鯨反対運動など の社会運動 37 な゙が挙げられる.このような政策移転で は，すでに認識されている問題を解決することよりも， ある事象が解決すべき問題であるという認識を多くのス テークホルダーに持たせることにその目標がある.

第二の目的は, 現場で起きている課題を解決するため に，海外の事例を参考にするという政策移転であり，そ の本質は，合理的な政策決定を前提とした学習導出論 ${ }^{15)}$ とほぼ同一である.

第三の目的は，国際機関や連携合意の中で，正統性 (legitimacy) を確保する手段として, 先行事例に倣った 政策を導入することを意味する，具体的には，EUへの 加盟条件を（実質的に）満足させるための導入 ${ }^{20}$, 官僚 の影響力を弱めようとする国際的圧力への対応としての 導入 $\left.{ }^{~}\right)$ ），国際金融機関による要求を一時的に満足させ るための導入 ${ }^{27}$, などが挙げられる. このような状況で は, 国内ではできるだけ現状を維持しつつ, 対外的には 他の政府と類似寸る政策を導入しているという印象を形 
成するという，分断（decoupling）が起こりうる. 実際, 企業ではそのような組織変容は一般的である ${ }^{40)}$. 結果と

して，名称や体制だけが表面的に移転される.

目的の 3 類型は，政策移転により受入側の文脈 (context) が受ける影響 ${ }^{8)}$ の許容度を軸としても整理で きる. 生存・適合目的であれば, 文脈の修正を最小限に とどめようとしているし，社会変革目的であれば文脈を 大きく変えることが期待されている.

\section{3. 政策移転の対象}

政策移転に関する既往研究では，政策移転の対象につ いてこれまでさまざまな類型化が試みられてきた. 本稿

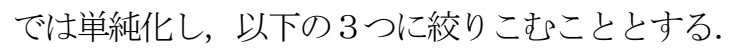

・制度・文化

・政策・事業

・シンボル

制度・文化は，政策や事業を制約する，上位（メタレベ ル）の概念を指し示寸. 日本の事例を挙げれば，制度と しては裁判一の国民参加，文化としては阪神淡路大震災 以降のボランティアへの関心の高まりなどが挙げられる. 特に, 文化の移転については, 移転の取り組みと, 文化 の変容との因果関係を事後的に立証することは極めて困 難であるが，環境 NGO や行政効率化を訴える政策シン クタンクのように, 特定の思想を社会に導入しようとす る者が，現実に存在し，文化の移転を試みていることも 事実である.

政策・事業の移転は，学習導出論 ${ }^{15)}$ や政策移転論 ${ }^{21)}$ で中心的に取り上げられている研究の対象であり, 詳し い説明はここでは省略する.

シンボルの移転とは, 名称の変更や, 機能自体は変化 しない体制の修正といったものであり，いわば実質的に はほぼ何も移転されていない状態を意味する。しかし， 現実の政策移転研究, 特に日本の政策移転の研究事例で は，シンボルの移転が多く取り上げられている．たとえ ば, Goldfinch ${ }^{6}$ による研究は, 日本の国立大学法人化は, 改革の儀式（ritual of reform）を通過するための儀礼であ って, 文科省による国立大学法人一の影響力は衰えてお らず，レトリックや表面的な法人形態が変化したに過ぎ ないと指摘している. カリブ海諸国における NPM の導 入も, 国際金融機関の指示でコンサルタントなどを導入 するも，実態としては公務員のスキル不足が主な原因と なり新制度は導入できない事態に至っている ${ }^{27}$. 従来の 政策移転論に基づけば，これらは「不十分な移転」 ${ }^{17}$ 事 例としてとらえることもできるが，政策移転を手段とし てとらえれば，その目的によっては，あえてシンボルだ け受容することも適切な対応策である可能性もある.

\section{4. 目的, 対象に合わせた政策移転技法}

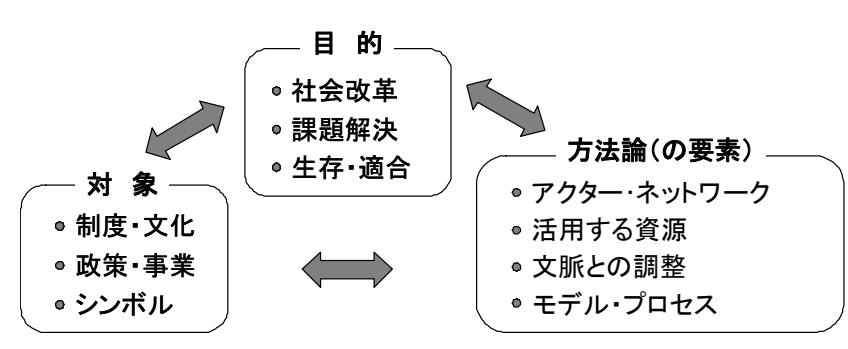

Fig. 2 政策移転ガイドラインの構成要素

このように，政策移転の目的と対象の多様性がみられ る中で，目的や対象を定めずに政策移転の方法論を定式 化することは難しい. 逆に, 目的と対象が定まれば, 適 切な政策移転の方法論をある程度一般化できると考えら れる．また，政策移転の目的と対象の間には関係性があ る. 生存・適合が目的であれば, シンボルを対象とする だけで十分に目的が果たせるだろうし, 社会改革が目的 であれば，制度・文化まで対象に含める必要があるだろ う. 目的, 対象, そして適切な方法論という 3 つの要素 はFig. 2 のように表現できる. 本稿では, 以下, 政策移 転の目的を軸に整理し，それぞれの目的に適した政策移 転の方法論を提示することとする.

\section{(1) 社会改革のための政策移転}

海外の先行事例を, 理想とする社会の実現のための説 得材料として利用するのであれば，政策移転におけるア クター・ネットワークは, 唱道連携フレームワーク (advocacy coalition framework: ACF) とみな寸ことができ る ${ }^{35}$. ACF は, アクターが多様な立場の人々で構成され る点では政策移転ネットワークと同じだが, ACF のアク ターが，共通の信念システム (belief system) に基づいて 連携する点に大きな違いがある. 政策移転の文脈で説明 すると, 海外の先行事例に興味があるだけでなく，その 背後にある価值観を共有する人々によってアクター・ネ ットワークが構成されるということだ.

具体的には, 政治家, NGO, シンクタンク, 経済団体, 学識経験者など, 社会改革を目指寸価值観を共有する 人々が主要アクターとなると想定される. また, 行政機 関も, 特に環境や福祉の分野で, 国民の行動変容を促そ うとする政策 (温暖化ガス排出削減, 労働時間縮減など) を推進する場合にはアクターとして参加することも考え られるし，官僚が個人としての立場でこのようなネット ワークに参加することは一般的だと考えられる.

政策移転を促進する手段として, 人的資源, メディア, 知的資源などを最大限活用する必要がある. 具体的には, 移転を推進するための組織機構が必要となり, ネットワ 一クの中核をなす NGO やシンクタンクがその役割を果 たすことができるだろうし，もしなければ何らかの組織 を立ち上げる必要がある.メディアとの連携も重要で, 
より多くの賛同を集めるための広報活動が必要である. 国際 NGO による意識変容を狙った戦略はまさにその先 例である ${ }^{37)}$. 海外情報については, ベスト・プラクティ スを中心に, 説得力のある情報を幅広く収集する必要が ある. そのような成功事例は従来の政策移転において活 用されてきた情報 ${ }^{30)}$ であり, 失敗事例に比べれば収集は 容易である。情報收集では，認知共同体 ${ }^{34)}$ のうな，学 識経験者の国際ネットワークを活用することもできる.

社会改革を目的とした政策移転では, 従来の制度・文 化などの文脈と, 移転しようとする制度・文化との間に 見られる齟踾を調整する必要性は少ない. 既存の制度や それに基づく権益等との調整を図るのではなく,むしろ, できる限り多くの国民から新たな制度への賛同を得るこ とで，国の制度や仕組みといった文脈を抜本的に変える ことが活動の目的である. ただし，政策や事業の詳細に 至るまで, 海外の仕組みを模倣することにも危険がある. メタなレベルでの変革に悪影響がないのであれば，ミク ロなレベルでの修正は受け入れ, Dolowitzのいう「不適 切な移転」77を防ぐほうが, 目的達成の可能性が高まる.

一連のプロセスとして考えれば, (1) 理想の社会像を 実現している海外事例を探索すること，(2) 同じ理想を 抱く国内キーパーソンを少数特定し, 求心力の強いネッ トワークを構築すること, (3) 学識経験者, NGO, シン クタンクなどを通じた海外ネットワークを構築すること, (4) メディアなどを通じて国内問題の存在と, 海外事例 の合理性について幅広い国民の理解を得ること，(5) ネ ットワーク内の政治家，官僚などを通じて政策の導入を 試みること，として整理できるだろう。

\section{(2) 問題解決のための政策移転}

学習導出論以降の問題意識は, ある所与の社会問題を 解決するための政策を立案する際, 最も「合理的」に海 外のアイディアを利用する方法にある. 問題解決のため の政策移転もまさにこの文脈に該当する.

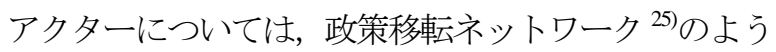
な, 移転そのものの実務に関わるグループに加えて, 対 象とする課題の解決に関心のあるステークホルダーも, 政策移転の方法論においては, そのアクターとして位置 ゔけるべきだろう. また, 課題解決の対象となる課題そ のものを, 問題構造化手法 ${ }^{45)}$ やステークホルダー分析手

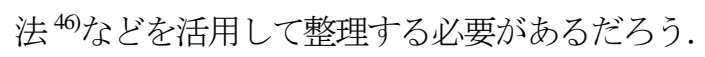

問題解決のための政策移転に活用寸る資源は, メディ アや社会運動ではなく，知的資源が中心となる．海外の 先行事例について, できるだけ多くの制度および実施事 例に関する情報を収集しなければならない。また,

Mossberger ら ${ }^{30)}$ が言うように, 政策移転では先行事例の 「成功」ばかり強調される傾向があるが，否定的側面， 「失敗」事例も含めた評価を入手する必要がある.

海外の先行事例に関する豊富な情報，そして解決しょ
うとする国内の政策課題の整理に基づき，国内の既存制 度，ステークホルダー等との調整を図る. その過程は, 政策移転であるからといって特別なものではなく, 従来 の政策形成過程論で検討されてきた, 政策形成の方法論 (たとえばコンセンサス・ビルディング手法 $\left.{ }^{47}\right)$ に従う ことになるだろう.

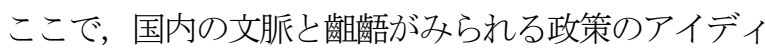
アを自動的に除外するような検討を加えてしまっては, 生存・適合のための政策移転と同じになってしまう. 課 題解決のためには, 海外先行事例に基づく政策案を優先 して制度を修正することが必要となる場合もあるし, 逆 に, 国内制度を優先して, 海外事例から知見を既存の制 度に合わせて適応化することが必要な場合もある ${ }^{8), 48) . ~}$

プロセスとしては, (1) 対応すべき課題についての事 前調査を行い, (2) 解決策の検討において, Rose ${ }^{311} の$ 学習 導出論に見られる政策移転プロセスを用いて情報収集を 行い，(3) 政策移転を行わないという選択肢を含めて, 現場の問題解決に適した政策を検討寸る，と表現できる だろう。つまり, 政策移転は, 通常の政策形成過程のサ ブシステムとして機能することになる.

\section{(3) 生存 ·適合のための政策移転}

国連や EU をはじめとする超国家的組織への参画条件 の満足や，2国間関係における政治的圧力への対応が必 要であれば，国内政策や制度への影響を最低限に抑えつ つ，政策を受け入れる「姿勢」をシンボルとして対外的 に見せる, 分断戦略が可能である. 実際に, 日本の政策 移転事例では, 改革などの看板を掲げつつ, 実際には従 前の組織や制度の保全が図られている 6),7。

国内一の影響を最小限に抑えるためには，政策形成過 程への参画を制限し，より実質的な政策移転を抑制する 必要がある. たとえば, 審議の場を設けるにしても, 研 究への関心が強く実践的な提言をしない学識経験者を集 める，あるいは行政職員の夕で集まるなど，国内アクタ 一のネットワークを「閉じた空間」6)とする必要がある.

同時に，政策移転一の圧力となる国際レジームについ ては, 国際関係論でいう 2 レベルゲーム ${ }^{42}$ として, 国内 の政策形成過程とは切り離して, 自国への影響を最小化 する交渉を必要となる. そのため国内とは逆に, 海外で はアクター・ネットワークを幅広く展開し, 必要に応じ て連携戦略 ${ }^{43}$ を活用する必要がある。

海外からの政策移転圧力に対抗するための資源の動員 としては, 従来政策の合理性と海外事例の問題を強調し た国内メディア戦略, カナダで見られるような海外メデ イアによる影響 ${ }^{44}$ の抑止, 従来政策の受益者によるデモ ンストレーション（たとえば農民による決起集会など） などが考えられる.ただし, 最終的に国際社会における 生存・適合のためにシンボルだけは移転することになる ため, 政策移転を完全に否定するようなフレームで動員 


\section{するべきではない.}

文脈との調整については，政策移転を求められている 具体的な内容と, 国内の組織体制, 法制度, 業界等の慣 行等と照合し，適合性の低い要素については政策移転の 対象から外す。 これも, 国内影響を最小化しつつ, 国際 的な正統性を調達するためのレトリックである. しかし， 政策移転を行ったという事実を対外的に示せるよう, 名 称を残す, 組織形態や法規制などの大枠だけは受容して 実質的には影響がないように詳細を書き換えるといった 対応が必要となる.

一連のプロセスとして生存・適合目的の政策移転を整 理すれば，(1) 国際交涉の場において自国の利害に適う 交涉努力を継続すること，(2) 生存・適合目的で何らか の政策を導入せざるを得ないと判断した場合には, 閉じ た議論の場を設けること, (3) 形式的な受容の方法論を 模索すること，(4) 既存の制度・政策の妥当性と海外事 例にみられる問題点を強調すること，(5) 移転の事実を 対外的に強調すること，となるだろう.

\section{5. 政策移転ガイドラインと現実の政策移転}

本稿では，政策移転に中心的に関わるアクターが，政 策移転に取り組む目的を特定した上で, 目的達成のため に活用できる方法論を政策移転ガイドラインとして検討 した. しかし現実には，さまざまなアクターが政策形成 過程に関与し，一部のアクターによる政策移転の試みを 阻止することもある. 実際, 政策移転の事例研究では, 社会改革としての意味合いが強い政策移転の取り組み (たとえば日本の行政改革 ${ }^{6), 7)}$, 旧東欧諸国の制度改革 20,21)）において，新たな制度・文化の導入が短期的には 阻まれる事例も多く見られる. このような事例では, 政 策移転を推進しようとする中心的アクターは社会改革を 目的に活動するものの，政策形成過程において，行政機 関など政策移転を受け入れる側のアクターの利害が卓越 し，最終的にシンボルしか移転されない事態に至ってい る. 前者の立場から見ると, そのような事例は「失敗」 と捉えられるのであろう。

本稿は, 目的に対応する 3 つの政策移転の方法論をガ イドラインとして提示したが，このガイドラインに従っ たとしても, 政策形成過程におけるさまざまなアクター 間の相互作用や, 既存の政治システムなどの構造的要因 等が作用して, 当初の目的に沿った形での政策移転が行 われないこともありえよう。

たとえば，Immergut ${ }^{499}$ は政治過程における制度的に担 保された拒否点（veto point）が理由となり, 新たな政策 の導入が阻まれる可能性を実証している. 政策移転の文 脈では, Radaelli50 は欧州化という一種の政策移転の試み が，加盟諸国の政策形成過程において，多様なアクター や制度的要因に影響を受ける可能性を整理おり, リーダ
ーシップが断片的で強力な拒否プレイヤー (veto player) が存在する場合には欧州化は難しいことを挙げているほ か, Haverland ${ }^{511}$ は, EU の包装および包装廃棄物指令と いう一種の政策移転が，文脈との適合性が一番高そうな ドイツで受容されなかった原因として制度的拒否点 (institutional veto points) の存在を示している.

Radaelli ${ }^{50}$ はさらに, 通貨統合のようにコアエグゼキュ ティブ (core executives) などのテクノクラートが支配し やすい政策であれば欧州化が実現しやすいが，交通自由 化政策のように多数のアクターが関与する政策では一部 の利害団体が欧州化を歪める可能性も指摘している.

このように，本稿の政策移転ガイドラインにしたがっ た取り組みを行ったとしても, 既存の政治システムなど の制度構造の影響を受けることで，期待した目的を果た せない可能性は十分にある. また，構造的制約でなくと も, 政策移転の対象とする事項について十分な政治的関

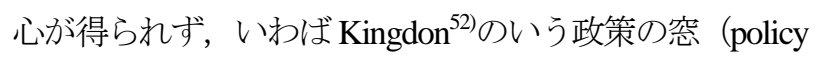
window）が開いていなければ，いかなる政策移転を試み たところで，新たな政策は導入されないかもしれない. このように, ガイドラインに従った取り組みも, その成 否は外生要因に影響を受ける。

特に，メタなレベルでの移転，すなわち新たな制度や 文化を持ち込むことで社会变革を図ろうとする政策移転 の場合に, 構造的制約との調整が問題となる. 逆に, 生 存や適合のためのシンボリックな政策移転の試みは, 既 存の国内政治システムなどの制度を逆に強化しうるもの であるから,構造的制約によって阻まれることは少ない． 結果として, 本節の最初に述べた日本の行政改革などの 事例のように, 当初は社会変革を目的とした政策移転を 試みた場合でも, 構造的制約が強くはたらき, 短期的に はシンボリックな政策移転へと変容してしまうことが起 きる. よって, 政策移転による社会変革を本当に狙う政 策家には, 政策の空が開く, あるいは狙っている社会変 革が可能となる政治的機会構造53)が訪れるのを待てるだ けの, 長期的な戦略が必要となるだろう.また, 国内で の政治的機会を閉ざされた途上国の NGO が，先進国の NGO と連携して国際機関や先進国政府から途上国政府 に外圧をかけてもらうブーメラン効果 ${ }^{54)}$ ように, 政治 システムという構造的障害をも変容させる戦略も必要と なるだろう.

このように，政策移転の試みは，政策形成過程におけ る調整を通じて, 当初の目的とは異なる結果一と至る可 能性がある. 本稿は, 政策移転に主体的に関わる者が活 用できる社会技術として政策移転ガイドラインを提示し たが，政策形成過程における多様なアクターが，ある政 策移転の取り組みに対して異なる利害関心を寄せている 状況で，社会として最適な政策移転に関する意思決定を 行うための方法論についてまでは検討していない，政策 
形成過程において，異なるアクターが異なる政策移転の 方法論を導入しようして対立している状況や，短期的に は変化しない構造的要因が支配する状況において，それ らの障壁を確実に乗り越えるための方法論についてまで 言及できていないことは，本稿で提示した政策移転ガイ ドラインの限界であるともいえる.

\section{5. 結論}

本稿は，政策移転の既往研究を幅広く整理した上で， 事例研究に基づく記述説明としての研究は活発に行われ ているものの，政策形成の現場で政策移転を活用する方 法論の研究が少ないことを明らかにした. 後半では, 政 策移転ガイドラインを提示寸ることを目的に，政策移転 の目的として, 社会改革, 課題解決, 生存・適合の 3 類 型を提示し, 既往研究を参照しながらそれぞれの目的に 適した政策移転の方法論を提示した。

今後の課題として, 提示した政策移転ガイドラインは, 事例研究をもとに構築した仮説でしかなく, 今後, ガイ ドラインを適用した実証研究の必要性が第一に挙げられ る. 多数の事例研究に基づく仮説であり, 再現性は高い と考えられるが，ガイドラインを意識的に活用した政策 移転事例が出てくれば，その有効性を実証できる. 第二 に, 政策移転と政策形成過程の関俰性をより学術的に精 査する必要がある. 今回の検討は, 政策移転に焦点を絞 ったが，現実の政策移転の取り組みは政策形成過程の一 部であり, 政策分析など他の政策サブシステムと併せ, その位置づけを総合的に検討する必要がある.たとえば, 国立大学法人化の事例も，政策移転を狭い意味でとらえ れば，英国のエージェンシー化に学ぼうという意識的な 政策移転の取り組みに加えて, 国会や審議会等における 利害調整，政策評価など, 複数のサブシステムから構成 される一連の政策形成過程とみなすことができるだろう. 第三に，日本の政策形成の言説（discourse）における海 外事例の意味についても考えておく必要がある. 海外の 事例を好むことは必ずしも日本固有の現象ではない55)が, 冒頭で述べたように，海外事例への参照は極めて頻繁に 行われており, 海外事例イコール先進的であるという海 外志向が日本の政策形成において無意識に共有されてい る可能性がある. 今回提示したガイドラインを十分に活 用するためには，海外志向の存在を認識した上で，課題 解決のために, 意識的に海外での失敗事例を収集したり, 逆に，社会変革のために，海外は先進的であるという認 識に訴えかけたりする必要がある，政策移転について考 える上で，日本の政策家が持つ海外に対する認識につい て，より一層の検討が必要である. 第四に, 政策移転が もたらす予期せぬ結果について, より一層の研究が期待
される. 本稿のガイドラインでは, 政策移転の方法論に よって, 制度・文化, 政策・事業, シンボルという移転 の対象を，それぞれ的確に操作できることを念頭に置い ているが, 実際には, 4.5.で述べたように, 政策形成過程 において, 政治システムなどの構造的要因や他のアクタ 一との相互作用により, 当初の思い通りに政策移転が実 現しないこともある，そのような，予期せぬ結果につい ての実証研究も, 政策形成過程の研究としては必要であ ろう。

\section{参考文献}

1) Campbell, J. (1992). How Policies Change: The Japanese government and the aging society. Princeton: Princeton Univ.

2)関岡 英之 (2004)『拒否できない日本』文藝春秋.

3) 首相官邸司法制度改革推進本部裁判員制度 - 刑事検討会 (2003).『外国法制に関する参考資料』http://www.kantei.go.jp/ jp/singi/sihou/kentoukai/saibanin/dai2/04.pdf [2009.9.11]

4) Westney, E. (1987). Imitation and Innovation. Cambridge, MA: Harvard Univ.

5) Nakano, K. (2004). Cross-National Transfer of Policy Ideas: Agencification in Britain and Japan. Governance, 17(2), 169-188.

6) Goldfinch, S. (2006). Rituals of Reform, Policy Transfer, and the National University Corporation Reforms of Japan, Governance, 19(4), 585-604.

7) 秋吉 貴雄 (2004) 「政策移転の政治過程 : アイディアの 受容と変容」『公共政策研究』4, 59-70.

8) Matsuura, M. (2008). Localizing Public Dispute Resolution in Japan: lessons from experiments with deliberative policymaking. Saarbrücken, Germany: VDM Verlag.

9) Dolowitz, D. and Marsh, D. (1996). Who Learns What from Whom: A review of the policy transfer literature. Political Studies, 44, 343-357.

10) Rose, R. (1991). What is Lesson Drawing. Journal of Public Policy, 11, 3-30.

11) de Jong, M. (1999). Institutional Transplantation: How to adopt good transport infrastructure decision-making ideas from other countries? Delft, Netherlands: Eburon.

12) Walker, J. (1969). The Diffusion of Innovations among the American States. American Political Sci. Review, 69, 880-899.

13) Majone, G (1996). The Rise of Statutory Regulation in Europe. In G. Majone (Ed.) Regulating Europe (pp. 47-60). New York, NY: Routledge.

14) Bennett, C. (1991). Review Article: What is policy convergence and what causes it? British Journal of Political Sci., 21, 215-233.

15) Rose, R. (1993). Lesson-Drawing in Public Policy: A guide to 
learning across time and space. Chatham, NJ: Chatham House.

16) Dolowitz, D., Hulme, R., Nellis, M. and O’Neil, F. (2000). Policy Transfer and British Social Policy: Learning from the USA? Philadelphia, PA: Open Univ. Press.

17) Dolowitz, D. and Marsh, D. (2000). Learning from Abroad: The role of policy transfer in contemporary policy-making, Governance, 13(1), 5-24.

18) Mitchell, R., Clark, W., Cash, D. and Dickson, N. (Eds.) (2006). Global Environmental Assessments: Information and Influence. Cambridge, MA: MIT Press.

19) Ladi, S. (2005). Globalisation, Policy Transfer and Policy Research Institutes. Northampton, MA: Edward Elgar.

20) Hough, D., Paterson, W. and Sloam, J. (2006). Learning from the West?: Policy, transfer and programmatic change in the communist successor parties of eastern and central Europe. New York, NY: Routledge.

21) Stead, D., de Jong, M. And Reinholde, I. (2008). Urban Transport Policy Transfer in Central and Eastern Europe. DISP 172, 44(1), 62-73.

22) Evans, M. and Davies, J. (1999). Understanding Policy Transfer: A multi-level, multi-disciplinary perspective. Public Administration, 77(2), 316-385.

23) Giddens, A. (1984). The Construction of Society: outline of the theory of structuration. Berkeley, CA: Univ. of California.

24) Bomberg, E. and Peterson, J. (2000). Policy Transfer and Europeanization: Passing the Heineken test? Queen's Papers on Europeanization, \#2.

25) Evans, M. (Ed.) (2004). Policy Transfer in Global Perspective. Burlington, VT: Ashgate.

26) Stone, D. (2000). Non-Govemmental Policy Transfer: The Strategies of Independent Policy Institutes. Governance, 13(1), 45-62.

27) Bissessar, A. M. (2002). Policy Transfer, New Public Management and Globalization: Mexico and the Caribbean. Lanham, MD: University Press of America.

28) Common, R. (2004). Public Management and Policy Transfer in South-East Asia. In Evans, M. (Ed.) Policy Transfer in Global Perspective. (pp. 143-161). Burlington, VT: Ashgate.

29) de Jong, M., Lalenis, K.,and Mamadouh, V. (Eds.) (2002). The Theory and Practice of Institutional Transplantation: Experiences with the transfer of policy institutions. Norwell, MA: Kluwer.

30) Mossberger, K. and Wolman, H. (2003). Policy Transfer as a Form of Prospective Policy Evaluation: Challenges and recommendations. Public Administration Review, 63(4), 428-440.

31) Rose, R. (2005). Learning from Comparative Public Policy: A practical guide. New York, NY: Routledge.
32) Cohen, M., March, J. and Olsen, J. (1972). A Garbage Can Model of Organizational Choice. Administrative Science Quarterly, 17(1), 1-25.

33) de Jong, M. (2009). Rose's '10 steps': why process messiness, history and culture are not vague and banal. Policy \& Politics, 37(1), 145-150.

34) Haas, P. (1992). Introduction: Epistemic Communities and International Policy Coordination. International Organization, 46(1), 1-35.

35) Sabatier, P. (1988). An Advocacy Coalition Framework of Policy Change and the Role of Policy-Oriented Learning Therein. Policy Sciences, 21(2-3), 129-168.

36) de Jong, M. (2009). Institutional transplantation. （制度移植論 研究会〔東京大学公共政策大学院, 2009年6月 29 日] 発 表資料）.

37) Wapner, P. (2002). Horizontal Politics: Transnational Environmental Activism and Global Cultural Change. Global Environmental Politics, 2(2), 37-59.

38) Keck, M. and Sikkink, K. (1998). Activists Beyond Borders: Advocacy networks in international politics. Ithaca, NY: Cornell.

39) Connors, D. (undated). Adapting Public Consultation to Different Political Cultures. http://www.connor.bc.ca/adapting. html [2009.9.11]

40) Meyer, J. and Rowan, B. (1977). Institutionalized Organization: Formal Structure as Myth and Ceremony. American Journal of Sociology, 83(2), 340-363.

41) Bennett, C. (1991). How States Utilize Foreign Evidence. Journal of Public Policy, 11(1), 31-54.

42) Putnam, R. (1988). Diplomacy and Domestic Politics: the logic of two-level games. International Organization, 42(3), 427-460.

43) Sebenius, J. (1994). Sequencing to Build Coalitions: With whom should I talk first? In Zeckerhauser, R., Keeney, R. and Sebenius, J. (Eds.) Wise Choices: Decisions, Games, and Negotiations (pp. 324-348) Cambridge, MA: HBS Press.

44) Hoberg, G (1991). Sleeping with an Elephant: The American influence on Canadian environmental regulation, Journal of Public Policy, 11(1), 107-132.

45）加藤浩徳 - 城山英明 - 中川善典「関係主体間の相互関係 に着目した広域交通計画におけるシナリオ分析手法の提 案」『社会技術研究論文集』,4,94-106.

46）松浦正浩・城山英明・鈴木達治郎「ステークホルダー分 析手法を用いたエネルギー・環境技術の導入普及の環境 要因の構造化」『社会技術研究論文集』, 5, 12-23.

47) Susskind, L. and Cruikshank, J. (2008). 『コンセンサス・ビル ディング入門 : 公共政策の交渉と合意形成の進め方』（城 山英明・松浦正浩訳）有斐閣（原著 2006 年）。

48) 松浦正浩. (2007).「文脈を考慮した合意形成プロセスの導 
入 : コンセンサス・ビルディング手法の適応化と組織変

革」『第 35 回土木計画学研究発表会・講演集』

49) Immergut, E. (1992). Health Politics: Interests and institutions in Western Europe. New York, NY: Cambridge Univ.

50) Radaelli, C. (2003). The Europeanization of Public Policy. In. Featherstone, K. and Radaelli, C. (Eds.) The Politics of Europeanization. (pp. 27-57). Oxford, UK: Oxford Univ.

51) Haverland, M. (2000). National Adaptation to European Integration: The importance of institutional veto points, Journal of Public Policy, 20, 80-103.

52) Kingdon, J. (1995). Agendas, Alternatives, and Public Policies (2nd Ed.). New York, NY: Addison-Wesley.

53) Tarrow, S. (1998). Power in Movement: Social movements and contentious politics. New York, NY: Cambridge Univ.

54) Keck, M. and Sikkink, K. (1998). Activists beyond Borders: Advocacy networks in international politics. Ithaca, NY: Cornell Univ.

55) Wolman, H. (1992). Understanding Cross national Policy Transfers: The case of Britain and the US. Governance, 5(1), 27-45.

\section{謝辞}

本研究は科研費 (20730091)の助成を受けたものである. また，中央環境審議会の資料確認は東京大学公共政策大 学院修士課程の富永華子さんの協力を得た. ここに記し て感謝の意を表します。

\section{付録}

i) 環境省ホームページ (http://www.env.go.jp/) に掲載されて いる資料を筆者が確認したもの. なお，同ホームページ に掲載されていない資料 37 点はカウントに含まない.

ii) 以下，政策形成における国際的な学習・影響など全般を 「政策移転」, Dolowitz らを中心とする政策移転に関する 研究を「政策移転論」と呼ぶ.

\title{
POLICY TRANSFER AS A POLICY-MAKING TOOL: A REVIEW
}

\begin{abstract}
Masahiro Matsuura ${ }^{1}$
${ }^{1}$ Ph.D. (Urban and Regional Planning) Associate Professor, University of Tokyo, Graduate School of Public Policy (E-mail:matsuura@pp.u-tokyo.ac.jp)

Foreign cases influence domestic policy making to some extent. In particular, after the launch of the European Union and the expansion of economic globalization in the 1990s, there is a growing interest in policy transfer-an phenomena of foreign influence in policy making. Most policy transfer research has been descriptive and prescriptive approaches to policy transfer are lacking. This article explored a set of approaches to policy transfer by drawing on a repertoire of case studies of policy transfer. The author argues that policy transfer processes, such as the network of actors, should be tailored to their policy transfer goals, such as social reform, problem-solving, and survival and compliance.
\end{abstract}

Key Words: policy transfer, lesson drawing, policy-making tool 